DOI: https://doi.org/10.24127/ajpm.v10i2.3103

\title{
MENINGKATKAN KEMAMPUAN BERPIKIR KRITIS MAHASISWA MELALUI REALISTIC MATHEMATIC EDUCATION (RME)
}

\author{
Elita Mega Selvia Wijaya ${ }^{1}$, Nathasa Pramudita Irianti ${ }^{{ }^{*}}$ \\ ${ }^{1,2 *}$ Universitas Tribhuwana Tunggadewi, Malang, Indonesia \\ *Corresponding author \\ E-mail:_elita.selvia@gmail.com ${ }^{1)}$ \\ $\underline{\text { nathasa1990@gmail.com }}^{2 *)}$
}

Received 16 September 2020; Received in revised form 22 June 2021; Accepted 28 June 2021

\begin{abstract}
Abstrak
Penelitian ini bertujuan untuk meningkatkan kemampuan berpikir kritis mahasiswa Program Studi Pendidikan Matematika melalui Pendekatan Realistic Mathematic Education (RME). Subjek penelitian ini adalah Mahasiswa Program Studi Pendidikan Matematika Universitas Tribhuwana Tunggadewi Malang sebanyak 37 mahasiswa. Metode penelitian yang digunakan adalah Penelitian Tindakan Kelas menurut Kemmis dan Mc Taggart yang terdiri dari empat tahap, yaitu perencanaan (plan), tindakan (action), pengamatan (observe), dan refleksi (reflect). Instrumen penelitian berupa perangkat pembelajaran yang terdiri dari Rencana Pelaksanaan Pembelajaran (RPP), Lembar Kerja Mahasiswa, soal tes, dan lembar observasi aktivitas mahasiswa yang digunakan untuk melihat kemampuan berpikir kritis mahasiswa. Hasil penelitian diolah dengan Teknik analisis data kualitatif dan deskriptif komparatif. Penelitian ini terdiri dari dua siklus dengan masing-masing siklus terdiri dari dua pertemuan. Hasil penelitian menunjukkan bahwa pendekatan Relistic Mathematic Education (RME) dapat meningkatkan kemampuan berpikir kritis mahasiswa. Peningkatan ini dapat dilihat dari hasil aktivitas mahasiswa yang mengalami peningkatan dari siklus pertama ke siklus kedua. Peningkatan itu nampak dari hasil obsevasi pertemuan 1 dan pertemuan 2 di siklus pertama sebesar 83,5\% dan 87,5\% meningkat menjadi 86\% dan 93\% di siklus kedua. Berdasarkan hasil penelitian ini dapat disimpulkan bahwa pendekatan Realistic Mathematic Education (RME) dapat meningkatkan kemampuan berpikir kritis mahasiswa.
\end{abstract}

Kata kunci: Kemampuan berpikir kritis; peningkatan; realistic mathematic education (RME)

\begin{abstract}
This study aims to improve students' critical thinking skills in the Mathematics Education Major through the Realistic Mathematics Education (RME) Approach. This research was given to 37 students of the Mathematics Education Program. The research method used is Class Action Research according to Kemmis and Mc Taggart which consists of four stages, namely plan, action, observe, and reflect. The research instrument is consisting of a Lesson Plan, Student Worksheets, test sheets, and student activity observation sheets which are used to see their critical thinking skills. The results of the study were processed using qualitative and descriptive comparative data analysis techniques. This research consists of two cycles with each cycle consisting of two meetings. The results showed that the Realistic Mathematics Education (RME) approach can improve students' critical thinking skills. This increase can be seen from the results of student activities that have increased from the first cycle to the second cycle. The increase was apparent from the results of observations of meeting 1 and meeting 2 in the first series of $83.5 \%$ and $87.5 \%$, which increased to $86 \%$ and $93 \%$ in the second cycle. Based on the results of this study it can be concluded that the Realistic Mathematics Education (RME) approach can improve students' critical thinking skills.
\end{abstract}

Keywords: Critical thinking ability; improvement; realistic mathematic education (RME)

This is an open access article under the Creative Commons Attribution 4.0 International License 
DOI: https://doi.org/10.24127/ajpm.v10i2.3103

\section{PENDAHULUAN}

Matematika diberikan dengan tujuan untuk memberikan bekal kepada peserta didik untuk dapat berpikir logis, kritis, analitis, sistematis, cermat, dan dapat menggunakan pola berpikir kreatif dalam kehidupan sehari-hari (Fatmahanik, 2016b). Lunenburg dan Zetriuslita dkk menyepakati bahwa berpikir kritis merupakan trend yang paling signifikan di dunia pendidikan dan memiliki hubungan yang dinamis antara bagaimana pendidik mengajar dan bagaimana peserta didik belajar (Lunenburg, 2011) (Zetriuslita, Ariawan, \& Nufus, 2016). Dari sini, dapat diketahui bahwa kemampuan berpikir kritis sangat penting untuk dimiliki oleh peserta didik.

Salah satu aplikasi matematika yang sering digunakan dalam belajar matematika dan penyelesaian masalah yang berkaitan dengan proses optimalisasi dari fungsi linear yang memenuhi batasan-batasan tertentu yang dinyatakan dalam bentuk persamaan dan pertidaksamaan adalah program linear. Program linear merupakan salah satu pokok bahasan matematika yang diajarkan di semester ganjil. Berdasarkan observasi awal di Program Studi Pendidikan Matematika Universitas Tribhuwana Tunggadewi, terlihat bahwa mahasiswa kurang memahami konsep program linear. Hal ini nampak dari 30 mahasiswa yang diamati, hanya 4 orang mahasiswa yang dapat mengubah masalah dari bentuk soal cerita ke dalam bentuk matematis. Hal ini mengindikasikan bahwa mahasiswa hanya menghafalkan materi dan rumus tanpa memahami konsep matematika sehingga akibatnya mahasiswa mempelajarinya hanya sebagai syarat untuk kelulusan. Hal ini sejalan dengan penelitian yang dilakukan oleh Irianti dan Wijaya yang menemukan bahwa siswa hanya sekedar menghafal dan belum benar-benar melaksanakan pembelajaran yang bermakna (Irianti \& Wijaya, 2019). Siswa pun menjadi kurang dapat memaksimalkan kemampuan berpikir kritisnya dikarenakan hanya menghafalkan materi yang diberikan (Dewanti, 2015).

Pendekatan realistic mathematic education atau yang biasa disebut dengan RME merupakan pendekatan pembelajaran matematika yang didasarkan pada dunia nyata dan kehidupan sehari-hari (Fatmahanik, 2016a). Menurut Ulfah dkk, melalui RME, peserta didik tidak hanya menerima materi yang diberikan, tetapi juga berkesempatan untuk reinvent (menemukan) matematika melalui praktek kegiatan sehari-hari yang mereka alami (Ulfah, Kowiyah, \& Fernandez, 2018). Beberapa penelitian mengenai RME yang dilakukan oleh Mashudi, Musrikah, Ulfah, Trisnawati, memberikan hasil yang positif bahwa pendekatan Realistic Mathematic Education (RME) dapat membantu siswa dengan membawa matematika yang abstrak ke dalam bentuk yang nyata (Mashudi, 2016) (Musrikah, 2016) (Ulfah et al., 2018) (Trisnawati, Pratiwi, \& Waziana, 2018). Dengan memanfaatkan realitas dan lingkungan yang dipahami peserta didik, pembelajaran bermakna yang tidak hanya sekedar menghafal akan lebih mudah untuk dicapai (Ningsih, 2014)

Berdasarkan latar belakang tersebut, penelitian ini bertujuan untuk meningkatkan kemampuan berpikir kritis mahasiswa Program Studi Pendidikan Matematika melalui pendekatan Realistic Mathematic Education (RME). 


\section{METODE PENELITIAN}

Jenis penelitian ini adalah Penelitian Tindakan Kelas (PTK) dengan fokus penelitian pada peningkatan kemampuan berpikir kritis. Penelitian ini bertujuan untuk meningkatkan kemampuan berpikir kritis mahasiswa dalam menyelesaikan masalah program linear. Subjek penelitian ini adalah 37 mahasiswa Program Studi Pendidikan Matematika Universitas Tribhuwana Tunggadewi angkatan 2018. Rancangan penelitian yang digunakan mengacu pada model Kemmis dan Mc Taggart, yang meliputi tahap (1) perencanaan (plan), (2) pelaksanaan penelitian (action), (3) pengamatan (observation), dan (4) refleksi (reflection) yang membentuk suatu siklus (Kemmis \& Taggart, 1992).

Di tahap perencanaan (plan), dilakukan dengan melakukan tes awal untuk mengetahui kemampuan prasyarat mahasiswa mengenai program linear. Sebelum tes dilakukan, instrument tes terlebih dahulu divalidasi oleh dua orang ahli di bidang matematika. Setelah melakukan tes awal, selanjutnya adalah menentukan subjek penelitian berdasarkan hasil yang didapatkan di tes awal dan mengindentifikasi kesulitan yang dialami oleh mahasiswa. Selanjutnya disusun perangkat pembelajaran yang didesain dengan menggunakan pendekatan Realistic Mathematic Education (RME).

Di tahap pelaksanaan penelitian (action) merupakan tahap implementasi terhadap rancangan pelaksanaan pembelajaran yang telah disusun sebelumnya dengan menggunakan pendekatan Realistic Mathematic Education (RME). Pada tahap ini, juga dilakukan tahap pengamatan (orservation) dengan menggunakan lembar observasi. Observasi ini dilakukan untuk melihat kesesuaian proses pembelajaran dengan langkahlangkah yang sudah disusun dengan menggunakan pendekatan Realistic Mathematic Education (RME).

Tahap terakhir adalah refleksi (reflection). Kegiatan ini dilakukan untuk mengevaluasi proses pembelajaran yang sudah dilaksanakan dengan pendekatan Realistic Mathematic Education (RME). Dari kelebihan dan kekurangan dari proses pembelajaran tersebut, selanjutnya digunakan sebagai pertimbangan dalam penyusunan rencana pelaksanaan pembelajaran di pertemuan selanjutnya. Instrumen penelitian berupa perangkat pembelajaran yang terdiri dari (1) Rencana Pelaksanaan Pembelajaran (RPP) yang digunakan untuk mengetahui kesesuaian peneliti dalam melaksanakan pembelajaran berdasarkan rancangan pembelajaran yang telah disusun; (2) lembar kerja mahasiswa dan soal tes yang digunakan untuk mengetahui pemahaman mahasiswa pada materi program linear; dan (3) lembar observasi aktivitas mahasiswa yang digunakan untuk melihat kemampuan berpikir kritis mahasiswa. Indikator kemampuan berpikir kritis dalam penelitian ini adalah kemampuan menggeneralisasi, kemampuan mengidentifikasi masalah, merumuskan masalah ke dalam model matematika dan mendedukasi dengan menggunakan prinsip matematika pada materi program linear. Teknik analisis data yang digunakan adalah teknik analisis data kualitatif dan deskriptif komparatif. Deskriptif komparatif dalam penelitian ini dengan membandingkan antara data observasi awal, siklus pertama dengan siklus kedua yang diperoleh bahwa secara berturut-turut pada siklus pertama dan siklus kedua terjadi peningkatan 
DOI: https://doi.org/10.24127/ajpm.v10i2.3103

sehingga penelitian telah selesai sampai dengan siklus kedua dan dapat disimpulkan untuk peningkatan kemampuan berpikir kritis mahasiswa. Selain itu, indikator keberhasilan dalam penelitian ini adalah mencapai kriteria ketuntasan belajar yaitu paling sedikit $85 \%$ indikator telah dicapai mahasiswa yang mengikuti kegiatan diskusi.

\section{HASIL DAN PEMBAHASAN}

Penelitian Tindakan Kelas ini dilakukan di Program Studi Pendidikan Matematika dengan menggunakan dua siklus, yaitu siklus pertama dan siklus kedua. Masing-masing siklus dilaksanakan sebanyak dua kali pertemuan. Rancangan penelitian yang yang dilakukan setiap siklus meliputi (1) perencanaan (plan) yaitu menyusun perangkat pembelajaran seperti RPP, LKM, Soal Tes, dan lembar observasi guru dan lembar observasi aktivitas siswa. Kemudian seluruh instrumen penelitian tersebut divalidasi oleh dua validator. (2) pelaksanaan penelitian (action), (3) pengamatan (observation), dan (4) refleksi (reflection).

Validasi terhadap perangkat pembelajaran dengan instrumen penelitian menggunakan pendekatan Realistic Mathematic Education (RME) seperti pada Tabel 1.

Tabel 1. Hasil validasi perangkat pembelajaran siklus pertama

\begin{tabular}{llcc}
\hline \multicolumn{2}{l}{ Jenis perangkat perkuliahan dan instrumen penelitian } & $\begin{array}{c}\text { Validator } \\
\text { I }\end{array}$ & $\begin{array}{c}\text { Validator } \\
\text { II }\end{array}$ \\
\hline Rencana pelaksanaan & Skor Total $\left(\mathrm{S}_{\mathrm{T}}\right)$ & 96 & 101 \\
perkuliahan & Persentase skor rata-rata $(\mathrm{SR})$ & $92 \%$ & $97 \%$ \\
& Kriteria SR & Valid*) $^{*}$ & Valid*) $^{*}$ \\
Lembar kerja & Skor Total $\left(\mathrm{S}_{\mathrm{T}}\right)$ & 63 & 65 \\
mahasiswa & Persentase skor rata-rata (SR) & $93 \%$ & $96 \%$ \\
& Kriteria SR & Valid*) & Valid*) $^{*}$ \\
Instrumen tes & Skor Total $\left(\mathrm{S}_{\mathrm{T}}\right)$ & 27 & 30 \\
& Persentase skor rata-rata (SR) & $84 \%$ & $94 \%$ \\
& Kriteria SR & Valid*) & Valid*) \\
Lembar observasi & Skor Total $\left(\mathrm{S}_{\mathrm{T}}\right)$ & 54 & 51 \\
aktivitas mahasiswa & Persentase skor rata-rata (SR) & $96 \%$ & $91 \%$ \\
& Kriteria SR & Valid*) & Valid*) \\
\hline
\end{tabular}

*) Valid tanpa revisi

Berdasarkan Tabel 1, diketahui bahwa semua perangkat pembelajaran untuk siklus pertama telah dinyatakan valid oleh semua validator. Setelah perangkat pembelajaran dinyatakan valid, barulah dapat digunakan untuk pembelajaran di siklus pertama. Hasil observasi yang dilakukan oleh pengamat satu (P1) dan pengamat dua (P2) di pertemuan pertama siklus pertama dengan mengacu pada lembar observasi aktivitas mahasiswa dalam perkuliahan seperti ditunjukkan pada Tabel 2.

Berdasarkan Tabel 2, hasil observasi aktivitas mahasiswa yang dilakukan oleh P1 dan P2 menunjukkan hasil baik dengan persentase skor ratarata $81 \%$ dari $\mathrm{P} 1$, dan $86 \%$ dari $\mathrm{P} 2$. Sehingga dapat disimpulkan bahwa rata-rata hasil observasi aktivitas mahasiswa pada pertemuan pertama siklus pertama adalah $83,5 \%$ yang termasuk kategori baik. 
DOI: https://doi.org/10.24127/ajpm.v10i2.3103

Tabel 2. Hasil Observasi Aktivitas Mahasiswa di pertemuan pertama siklus pertama

\begin{tabular}{|c|c|c|c|c|}
\hline \multirow[t]{2}{*}{ Tahap } & \multirow[t]{2}{*}{ Indikator } & \multirow[t]{2}{*}{ Deskriptor } & \multicolumn{2}{|c|}{$\begin{array}{l}\text { Penilaian } \\
\text { Pengamat }\end{array}$} \\
\hline & & & I & II \\
\hline \multirow[t]{16}{*}{ Inti } & Identifikasi & a. Membaca masalah yang diberikan & 4 & 4 \\
\hline & unsur-unsur & b. Berusaha memahami persoalan & 5 & 5 \\
\hline & & $\begin{array}{l}\text { c. Berdiskusi dalam kelompok untuk } \\
\text { memahami jenis persoalan }\end{array}$ & 4 & 4 \\
\hline & & $\begin{array}{l}\text { d. Berdiskusi dalam kelompok untuk } \\
\text { menentukan jenis variabel aktivitas }\end{array}$ & 4 & 5 \\
\hline & $\begin{array}{l}\text { Perumusan } \\
\text { masalah ke }\end{array}$ & $\begin{array}{l}\text { a. Saling berkerja sama dalam } \\
\text { kelompok }\end{array}$ & 5 & 5 \\
\hline & bentuk & b. Aktif bekerja sama dalam kelompok & 5 & 4 \\
\hline & matematik & $\begin{array}{l}\text { c. Aktif menyampaikan ide dalam } \\
\text { menentukan variabel fungsi obyektif }\end{array}$ & 4 & 4 \\
\hline & & $\begin{array}{l}\text { d. Aktif menyampaikan ide dalam } \\
\text { menentukan variabel fungsi kendala }\end{array}$ & 4 & 5 \\
\hline & $\begin{array}{l}\text { Penerapan } \\
\text { strategi }\end{array}$ & $\begin{array}{l}\text { a. Aktif menyampaikan ide untuk } \\
\text { menyelesaiakan persoalan }\end{array}$ & 4 & 5 \\
\hline & penyelesaian & b. Mengisi lembar kerja & 4 & 4 \\
\hline & masalah & c. Menjawab persoalan & 4 & 4 \\
\hline & & d. Menuliskan hasil diskusi & 4 & 4 \\
\hline & Interpretasi & $\begin{array}{l}\text { a. Menyampaikan hasil diskusi dengan } \\
\text { baik dan jelas }\end{array}$ & 4 & 4 \\
\hline & & $\begin{array}{l}\text { b. Memperhatikan pendapat/penjelasan } \\
\text { dari kelompok lain }\end{array}$ & 3 & 4 \\
\hline & & c. Menghargai pendapat teman & 4 & 4 \\
\hline & & d. Membuat suatu kesepakatan bersama & 3 & 4 \\
\hline \multicolumn{2}{|c|}{ Jumlah } & & 65 & 69 \\
\hline \multicolumn{3}{|c|}{ Persentase skor rata-rata (SR) } & $81 \%$ & $86 \%$ \\
\hline \multicolumn{3}{|c|}{ Kriteria } & Baik & Baik \\
\hline
\end{tabular}

Hasil observasi yang dilakukan oleh pengamat satu (P1) dan pengamat dua (P2) di pertemuan kedua siklus pertama dengan mengacu pada lembar observasi aktivitas mahasiswa dalam perkuliahan seperti ditunjukkan pada Tabel 3.

Tabel 3. Hasil observasi aktivitas mahasiswa di pertemuan kedua siklus pertama

\begin{tabular}{|c|c|c|c|c|}
\hline \multirow[t]{2}{*}{ Tahap } & \multirow[t]{2}{*}{ Indikator } & \multirow[t]{2}{*}{ Deskriptor } & \multicolumn{2}{|c|}{$\begin{array}{l}\text { Penilaian } \\
\text { Pengamat }\end{array}$} \\
\hline & & & $\mathbf{I}$ & II \\
\hline \multirow[t]{4}{*}{ Inti } & Identifikasi & a. Membaca masalah yang diberikan & 5 & 5 \\
\hline & unsur-unsur & b. Berusaha memahami persoalan & 5 & 5 \\
\hline & & $\begin{array}{l}\text { c. Berdiskusi dalam kelompok untuk } \\
\text { memahami jenis persoalan }\end{array}$ & 4 & 4 \\
\hline & & $\begin{array}{l}\text { d. Berdiskusi dalam kelompok untuk } \\
\text { menentukan jenis variabel aktivitas }\end{array}$ & 4 & 5 \\
\hline
\end{tabular}


DOI: https://doi.org/10.24127/ajpm.v10i2.3103

\begin{tabular}{|c|c|c|c|c|}
\hline \multirow[t]{2}{*}{ Tahap } & \multirow[t]{2}{*}{ Indikator } & \multirow[t]{2}{*}{ Deskriptor } & \multicolumn{2}{|c|}{$\begin{array}{l}\text { Penilaian } \\
\text { Pengamat }\end{array}$} \\
\hline & & & I & II \\
\hline & $\begin{array}{l}\text { Perumusan } \\
\text { masalah ke }\end{array}$ & $\begin{array}{l}\text { a. Saling berkerja sama dalam } \\
\text { kelompok }\end{array}$ & 5 & 5 \\
\hline & bentuk & b. Aktif bekerja sama dalam kelompok & 5 & 5 \\
\hline & matematik & c. Aktif menyampaikan ide dalam & 5 & 5 \\
\hline & & $\begin{array}{l}\text { menentukan variabel fungsi obyektif } \\
\text { d. Aktif menyampaikan ide dalam } \\
\text { menentukan variabel fungsi kendala }\end{array}$ & 5 & 5 \\
\hline & $\begin{array}{l}\text { Penerapan } \\
\text { strategi }\end{array}$ & $\begin{array}{l}\text { a. Aktif menyampaikan ide untuk } \\
\text { menyelesaiakan persoalan }\end{array}$ & 4 & 4 \\
\hline & penyelesaian & b. Mengisi lembar kerja & 4 & 4 \\
\hline & masalah & c. Menjawab persoalan & 4 & 4 \\
\hline & & d. Menuliskan hasil diskusi & 4 & 4 \\
\hline & Interpretasi & $\begin{array}{l}\text { a. Menyampaikan hasil diskusi dengan } \\
\text { baik dan jelas }\end{array}$ & 4 & 4 \\
\hline & & $\begin{array}{l}\text { b. Memperhatikan pendapat/penjelasan } \\
\text { dari kelompok lain }\end{array}$ & 4 & 4 \\
\hline & & c. Menghargai pendapat teman & 4 & 4 \\
\hline & & d. Membuat suatu kesepakatan bersama & 4 & 4 \\
\hline \multicolumn{2}{|c|}{ Jumlah } & & 70 & 71 \\
\hline \multicolumn{3}{|c|}{ Persentase Skor Rata-Rata (SR) } & $87 \%$ & $88 \%$ \\
\hline \multicolumn{3}{|c|}{ Kriteria } & Baik & Baik \\
\hline
\end{tabular}

Dari hasil observasi aktivitas mahasiswa pada Tabel 3 diperoleh bahwa perkuliahan pada pertemuan kedua aktivitas mahasiswa berdasarkan pengamatan P1 sebesar $87 \%$ (kriteria baik), sedangkan pengamatan P2 sebesar $88 \%$ (kriteria baik), maka dapat disimpulkan bahwa rata-rata observasi aktivitas mahasiswa pada pertemuan kedua siklus pertama sebesar 87,5\% (kriteria baik).

Dari hasil diskusi LKM I diketahui bahwa persentase mahasiswa yang memperoleh skor $\geq 65$ sebesar 96\% dari keseluruhan mahasiswa yang mengikuti kegiatan diskusi. Hasil persentase pencapaian setiap indikator yang diteliti pada LKM II pertemuan kedua menunjukkan beberapa indikator telah mencapai $100 \%$. Namun terdapat beberapa indikator yang belum mencapai skor maksimum sebesar $88 \%$, hal ini menunjukkan bahwa perkuliahan pada siklus pertama memenuhi kriteria ketuntasan belajar yaitu paling sedikit $85 \%$ indikator telah dicapai mahasiswa yang mengikuti kegiatan diskusi. Berdasarkan hasil analisa data dari uraikan di atas maka kegiatan perkuliahan pada siklus pertama belum mencapai kriteria keberhasilan. Dengan demikian disimpulkan bahwa siklus pertama belum memenuhi kriteria keberhasilan yang ditetapkan dalam penelitian tindakan kelas ini sehingga harus dilaksanakan siklus selanjutnya.

Sebelum dilakukan proses pembelajaran di siklus kedua, dilakukan validasi terhadap perangkat pembelajaran dengan instrumen penelitian untuk siklus kedua menggunakan pendekatan Realistic Mathematic Education (RME) seperti pada Tabel 4. 
DOI: https://doi.org/10.24127/ajpm.v10i2.3103

Tabel 4. Hasil validasi perangkat pembelajaran siklus kedua

\begin{tabular}{|c|c|c|c|c|}
\hline \multicolumn{2}{|c|}{$\begin{array}{l}\text { Jenis perangkat perkuliahan dan instrumen } \\
\text { penelitian }\end{array}$} & \multirow{2}{*}{$\begin{array}{c}\begin{array}{c}\text { Validator } \\
\text { I }\end{array} \\
92\end{array}$} & \multirow{2}{*}{$\begin{array}{c}\begin{array}{c}\text { Validator } \\
\text { II }\end{array} \\
101\end{array}$} & $\begin{array}{c}\text { Validator } \\
\text { III }\end{array}$ \\
\hline Rencana & Skor total $\left(\mathrm{S}_{\mathrm{T}}\right)$ & & & 96 \\
\hline pelaks & Persentase skor rata-rata (SR) & $89 \%$ & $97 \%$ & $92 \%$ \\
\hline perkuliahan & Kriteria SR & Valid*) & Valid*) & Valid*) \\
\hline Lembar kerja & Skor Total $\left(\mathrm{S}_{\mathrm{T}}\right)$ & 63 & 65 & 65 \\
\hline mahasiswa & Persentase skor rata-rata (SR) & $93 \%$ & $96 \%$ & $96 \%$ \\
\hline & Kriteria SR & Valid*) & Valid*) & Valid*) \\
\hline \multirow[t]{3}{*}{ Instrumen tes } & Skor Total $\left(\mathrm{S}_{\mathrm{T}}\right)$ & 27 & 30 & 29 \\
\hline & Persentase skor rata-rata $(\mathrm{SR})$ & $84 \%$ & $94 \%$ & $91 \%$ \\
\hline & Kriteria SR & Valid*) & Valid*) & Valid*) \\
\hline Lembar & Skor Total $\left(\mathrm{S}_{\mathrm{T}}\right)$ & 46 & 54 & 51 \\
\hline observasi & Persentase skor rata-rata $(\mathrm{SR})$ & $82 \%$ & $96 \%$ & $91 \%$ \\
\hline $\begin{array}{l}\text { aktivitas } \\
\text { mahasiswa }\end{array}$ & Kriteria SR & Valid*) & Valid*) & Valid*) \\
\hline
\end{tabular}

*) Valid tanpa revisi

Berdasarkan Tabel 4, diketahui bahwa semua perangkat pembelajaran untuk siklus kedua telah dinyatakan valid, baik oleh Validator I, Validator II, dan Validator III.

Setelah perangkat pembelajaran dinyatakan valid, barulah dapat digunakan untuk pembelajaran di siklus kedua. Hasil observasi yang dilakukan oleh P1 dan P2 di pertemuan pertama siklus kedua dengan mengacu pada lembar observasi aktivitas mahasiswa dalam perkuliahan seperti ditunjukkan pada Tabel 5.

Tabel 5. Hasil Observasi Aktivitas Mahasiswa di pertemuan pertama siklus kedua

\begin{tabular}{|c|c|c|c|c|}
\hline \multirow{2}{*}{ Tahap } & \multirow{2}{*}{ Indikator } & \multirow{2}{*}{ Deskriptor } & \multicolumn{2}{|c|}{ Penilaian } \\
\hline & & & $\mathbf{P 1}$ & $\mathbf{P 2}$ \\
\hline \multirow[t]{11}{*}{ Inti } & Identifikasi & a. Membaca masalah yang diberikan & 4 & 4 \\
\hline & unsur-unsur & b. Berusaha memahami persoalan & 5 & 5 \\
\hline & & $\begin{array}{l}\text { c. Berdiskusi dalam kelompok untuk memahami } \\
\text { jenis persoalan } \\
\text { d. Berdiskusi dalam kelompok untuk }\end{array}$ & 4 & 4 \\
\hline & Perumusan & a. Saling berkerja sama dalam kelompok & 4 & 4 \\
\hline & masalah ke & b. Aktif bekerja sama dalam kelompok & 5 & 5 \\
\hline & $\begin{array}{l}\text { bentuk } \\
\text { matematik }\end{array}$ & $\begin{array}{l}\text { c. Aktif menyampaikan ide dalam menentukan } \\
\text { variabel fungsi obyektif }\end{array}$ & 5 & 5 \\
\hline & & $\begin{array}{l}\text { d. Aktif menyampaikan ide dalam menentukan } \\
\text { variabel fungsi kendala }\end{array}$ & 5 & 5 \\
\hline & $\begin{array}{l}\text { Penerapkan } \\
\text { strategi }\end{array}$ & $\begin{array}{l}\text { a. Aktif menyampaikan ide untuk } \\
\text { menyelesaiakan persoalan }\end{array}$ & 4 & 4 \\
\hline & penyelesaian & b. Mengisi lembar kerja & 5 & 5 \\
\hline & masalah & c. Menjawab persoalan & 4 & 4 \\
\hline & & d. Menuliskan hasil diskusi & 4 & 4 \\
\hline
\end{tabular}


DOI: https://doi.org/10.24127/ajpm.v10i2.3103

\begin{tabular}{llcc}
\hline \multirow{2}{*}{ Tahap Indikator } & \multicolumn{1}{c}{ Deskriptor } & \multicolumn{2}{c}{ Penilaian } \\
\cline { 3 - 4 } & \multicolumn{1}{c}{ P1 } & P2 \\
\hline Interpretasi & $\begin{array}{l}\text { a. Menyampaikan hasil diskusi dengan baik dan } \\
\text { jelas } \\
\text { b. Memperhatikan pendapat/penjelasan dari } \\
\text { kelompok lain }\end{array}$ & 4 & 4 \\
& $\begin{array}{l}\text { c. Menghargai pendapat teman } \\
\text { d. Membuat suatu kesepakatan bersama }\end{array}$ & 4 & 4 \\
& & 3 & 4 \\
\hline Jumlah & & $\mathbf{6 8}$ & $\mathbf{7 0}$ \\
\hline Persentase Skor Rata-Rata (SR) & $\mathbf{8 5 \%}$ & $\mathbf{8 7 \%}$ \\
\hline Kriteria & & Baik & Baik \\
\hline
\end{tabular}

Berdasarkan Tabel 5 di atas,
dapat disimpulkan bahwa hasil observasi aktivitas mahasiswa yang dilakukan oleh P1 dan P2 menunjukkan hasil baik dengan persentase skor ratarata $85 \%$ dari $\mathrm{P} 1$, dan $87 \%$ dari $\mathrm{P} 2$. Sehingga dapat disimpulkan bahwa rata-rata observasi aktivitas mahasiswa pada pertemuan pertama siklus kedua sebesar $86 \%$ dalam kriteria baik.

Hasil observasi yang dilakukan oleh P1 dan P2 di pertemuan kedua siklus kedua dengan mengacu pada lembar observasi aktivitas mahasiswa dalam perkuliahan seperti ditunjukkan pada Tabel 6.

Tabel 6. Hasil Observasi Aktivitas Mahasiswa di pertemuan kedua siklus kedua

\begin{tabular}{|c|c|c|c|c|}
\hline \multirow{2}{*}{ Tahap } & \multirow{2}{*}{ Indikator } & \multirow{2}{*}{ Deskriptor } & \multicolumn{2}{|c|}{ Penilaian } \\
\hline & & & P1 & $\mathbf{P 2}$ \\
\hline \multirow[t]{14}{*}{ Inti } & \multirow{4}{*}{$\begin{array}{l}\text { Identifikasi } \\
\text { unsur-unsur }\end{array}$} & a. Membaca masalah yang diberikan & 5 & 5 \\
\hline & & b. Berusaha memahami persoalan & 5 & 5 \\
\hline & & c. Berdiskusi dalam kelompok untuk & 4 & \\
\hline & & $\begin{array}{l}\text { memahami jenis persoalan } \\
\text { d. Berdiskusi dalam kelompok untuk } \\
\text { menentukan jenis variabel aktivitas }\end{array}$ & 5 & 5 \\
\hline & \multirow{4}{*}{$\begin{array}{l}\text { Perumusan } \\
\text { masalah ke } \\
\text { bentuk } \\
\text { matematik }\end{array}$} & a. Saling berkerja sama dalam kelompok & 5 & 5 \\
\hline & & b. Aktif bekerja sama dalam kelompok & 4 & 5 \\
\hline & & $\begin{array}{l}\text { c. Aktif menyampaikan ide dalam } \\
\text { menentukan variabel fungsi obyektif }\end{array}$ & 5 & 5 \\
\hline & & $\begin{array}{l}\text { d. Aktif menyampaikan ide dalam } \\
\text { menentukan variabel fungsi kendala }\end{array}$ & 5 & 5 \\
\hline & \multirow{4}{*}{$\begin{array}{l}\text { Penerapan } \\
\text { strategi } \\
\text { penyelesaian } \\
\text { masalah }\end{array}$} & $\begin{array}{l}\text { a. Aktif menyampaikan ide untuk } \\
\text { menyelesaiakan persoalan }\end{array}$ & 5 & 5 \\
\hline & & b. Mengisi lembar kerja & 4 & 4 \\
\hline & & c. Menjawab persoalan & 4 & 4 \\
\hline & & d. Menuliskan hasil diskusi & 4 & 4 \\
\hline & \multirow[t]{2}{*}{ Interpretasi } & $\begin{array}{l}\text { a. Menyampaikan hasil diskusi dengan } \\
\text { baik dan jelas }\end{array}$ & 5 & 5 \\
\hline & & $\begin{array}{l}\text { b. Memperhatikan pendapat/penjelasan } \\
\text { dari kelompok lain }\end{array}$ & 4 & 4 \\
\hline
\end{tabular}


DOI: https://doi.org/10.24127/ajpm.v10i2.3103

\begin{tabular}{llcc}
\hline \multirow{2}{*}{ Tahap Indikator } & \multirow{2}{*}{ Deskriptor } & \multicolumn{2}{c}{ Penilaian } \\
\cline { 3 - 4 } & c. Menghargai pendapat teman & P1 & P2 \\
\hline & d. Membuat suatu kesepakatan bersama & 4 & 4 \\
\hline Jumlah & & $\mathbf{7 6}$ & $\mathbf{7 3}$ \\
\hline Persentase Skor Rata-Rata (SR) & $\mathbf{9 5 \%}$ & $\mathbf{9 1 \%}$ \\
\hline Kriteria & $\begin{array}{c}\text { Sangat } \\
\text { Baik }\end{array}$ & $\begin{array}{c}\text { Sangat } \\
\text { Baik }\end{array}$ \\
\hline
\end{tabular}

Dari hasil observasi perkuliahan pada pertemuan kedua yag ditunjukkan pada tabel 6, dapat disimpulan bahwa aktivitas mahasiswa berdasarkan pengamatan P1 sebesar 95\% sehingga dalam kriteria sangat baik, sedangkan pengamatan P2 sebesar $91 \%$ dalam kriteria sangat baik. Sehingga dapat disimpulkan bahwa rata-rata observasi aktivitas mahasiswa pada pertemuan kedua siklus kedua sebesar 93\% dalam kriteria sangat baik.

Dari hasil diskusi LKM diketahui bahwa persentase mahasiswa yang memperoleh skor $\geq 65 \%$ sebesar $91 \%$ dari keseluruhan mahasiswa yang mengikuti kegiatan diskusi kelompok, hal ini menunjukan bahwa perkuliahan pada siklus kedua memenuhi kriteria ketuntasan belajar yaitu paling sedikit $85 \%$ dari jumlah indikator yang diteliti. Berdasarkan hasil analisa data dari uraikan di atas maka kegiatan perkuliahan pada siklus kedua telah mencapai kriteria keberhasilan. Dengan demikian disimpulkan bahwa siklus kedua telah memenuhi kriteria keberhasilan yang ditetapkan dalam penelitian tindakan kelas ini.

Dari paparan di atas, nampak bahwa pendekatan Realistic Mathematic Education dapat meningkatkan kemampuan berpikir kritis mahasiswa Program Studi Pendidikan Matematika Universitas Tribhuwana Tunggadewi. Hal ini dapat dilihat dapat dilihat dari peningkatan secara berturut-turut antara data observasi awal, hasil aktivitas mahasiswa siklus pertama dan hasil aktivitas mahasiswa siklus kedua. Peningkatan itu nampak dari hasil obsevasi awal pertemuan 1 dan pertemuan 2 sebesar $50 \%$ dan $65 \%$, sehingga ada peningkatan secara berturut-turut yaitu pertemuan 1 dan pertemuan 2 di siklus pertama sebesar $83,5 \%$ dan $87,5 \%$ di siklus pertama meningkat menjadi $86 \%$ dan $93 \%$ di siklus kedua.

Penelitian ini telah melengkapi dan memperkuat penelitian sebelumnya mengenai pendekatan Realistic Mathematic Education. Trisnawati dkk melakukan penelitian terdapat pengaruh Pendekatan Realistic Mathematic Education (RME) pada kemampuan berkomunikasi matematis siswa. Dari penelitian yang dilakukan, menunjukkan hasil bahwa pendekatan Realistic Mathematic Education (RME) dapat meningkatkan kemampuan komunikasi matematis siswa kelas XI IPS 1 SMA Muhammadiyah 5 Yogyakarta (Trisnawati et al., 2018).

Yang membedakan dengan penelitian sebelumnya, penelitian ini ingin melihat pengaruh pendekatan Realistic Mathematic Education (RME) pada kemampuan berpikir kritis mahasiswa program Studi Pendidikan Matematika. Karena kemampuan dalam berpikir kritis juga sangat penting dan dibutuhkan dalam pemecahan masalah matematika. Kemampuan berpikir kritis yang meningkat bisa dilihat dari peningkatan aktivitas mahasiswa dan 
juga hasil LKM mahasiswa. Hal ini didukung oleh penelitian Walfajri dkk yang menyimpulkan bahwa siswa dengan kemampuan berpikir kritis yang tinggi membuat hasil belajarnya pun meningkat (Walfajri \& Harjono, 2019).

\section{KESIMPULAN DAN SARAN}

Berdasarkan hasil dan pembahasan dapat disimpulkan bahwa pendekatan Realistic Mathematic Education (RME) dapat meningkatkan kemampuan berpikir kritis mahasiswa Program Studi Pendidikan Matematika.

Saran untuk penelitian selanjutnya, data dari hasil penelitian ini dapat digunakan sebagai pijakan dasar dalam rangka menentukan permasalahan penelitian, sehingga hasil penelitian akan datang memiliki makna yang lebih tinggi bagi upaya peningkatan perkuliahan matematika.

\section{DAFTAR PUSTAKA}

Dewanti, S. S. (2015). Upaya Mengembangkan Kemampuan Berpikir Kritis melalui Pembelajaran Menggunakan Bahan Ajar Geometri ANalitik Berbasis Guided Discovery. AdMathEdu, 5(2), 171-182.

Fatmahanik, U. (2016a). Membentuk Karakter Peserta Didik Melalui Pembelajaran Matematika Realistik Di Madrasah Ibtidaiyah (Mi). Cendekia: Jurnal Kependidikan Dan Kemasyarakatan, 14(1), 107-122. https://doi.org/10.21154/cendekia. v14i1.550

Fatmahanik, U. (2016b). Realistic Mathematic Education (RME) Dalam Meningkatkan Hasil Belajar Matematika. Ibriez: Jurnal Kependidikan Dasar Islam Berbasis Sains, 1(1), 19-34. https://doi.org/10.21154/ibriez.v1i1.5
Irianti, N. P., \& Wijaya, E. M. S. (2019). Program Belajar Siswa Berbasis Prinsip Progressive Differentiation dan Intergrative Reconciliation. JIPM (Jurnal Ilmiah Pendidikan Matematika), 7(2), $\quad$ 74-84. https://doi.org/10.25273/jipm.v7i2. 3280

Jonhson, E. B. (2007). Contextual Teaching \& Learning: Menjadikan Kegiatan Belajar-Mengajar Mengasyikkan dan Bermakna. 345. Kemmis, S., \& Taggart, R. M. (1992). The Action Research Planner. Victoria: Deakin University.

Lunenburg, F. C. (2011). Critical Thinking and Constructivism Techniques for Improving Student Achievement. National Forum of Teacher Education, 21(3), 1-9. Retrieved from http://www.nationalforum.com/Ele ctronic Journal Volumes/Lunenburg, Fred C. Critical Thinking \& $\begin{array}{llll}\text { Constructivism } & \text { V21 N3 } 2011\end{array}$ NFTJ.pdf

Mashudi. (2016). Penerapan Pendekatan Realistik untuk Meningkatkan Hasil Belajar Siswa Kelas V pada Mata Pelajaran Matematika Pokok Bahasan Sifat-sifat Bangun Ruang. Jpsd, 2(1), 50-63.

Musrikah, M. (2016). Model Pembelajaran Matematika Realistik sebagai Optimalisasi Kecerdasan Logika Matematika pada Siswa SD/MI. Ta'allum: Jurnal Pendidikan Islam, 4(1), 118.

https://doi.org/10.21274/taalum.2016. 4.01.1-18

Ningsih, S. (2014). Realistic Mathematics Education: Model Alternatif Pembelajaran Matematika Sekolah. JPM IAIN Antasari, 1(2), 73-94. 
DOI: https://doi.org/10.24127/ajpm.v10i2.3103

Trisnawati, T., Pratiwi, R., \& Waziana, W. (2018). The effect of realistic mathematics education on student's mathematical communication ability. Malikussaleh Journal of Mathematics Learning (MJML), 1(1), 31. https://doi.org/10.29103/mjml.v1i1 .741

Ulfah, S., Kowiyah, \& Fernandez, D. (2018). The Difference of Student Mathematical Concept Understanding Ability using Realistic Mathematic Education and Problem Solving. Jurnal Inovasi Pendidikan Dasar, 3(2), 16. Retrieved from http://jipd.uhamka.ac.id/index.php/ jipd/article/view/48

Zetriuslita, Z., Ariawan, R., \& Nufus, H. (2016). Analisis Kemampuan Berpikir Kritis Matematis Mahasiswa Dalam Menyelesaikan Soal Uraian Kalkulus Integral Berdasarkan Level Kemampuan Mahasiswa. Infinity Journal, 5(1), 56.

https://doi.org/10.22460/infinity.v5 i1.p56-66 